\title{
Impact of Information Technology on Indian Politics
}

\author{
Meenakshi Bansal
}

\begin{abstract}
Over the years, the Indian politics has gone through tremendous transformation. Amidst these, some changes are positives while others end as bittern experiences. The most positive changes in the Indian political system with the advent of information technology are transparency and accountability. With the help of IT, now public has become more aware about their role as the citizens. People know about dos and don'ts in political system. The technology has changed the life of many and makes it simple and more responsive. The main objective of this paper is to analyse the impact of information technology on Indian politics. The research methodology is explanatory in nature and for data collection; it is confined upto only secondary sources which includes journals, websites, etc. After going through the detailed analysis on the impact of information technology on Indian politics, it can be said that there are both positive and negative impacts. The need of the hour is to minimise the negative impacts and maximise the positive impacts. As in the age of digitalisation, we cannot ignore technology. We should try to use the information technology to make the Indian politics more responsive not to degrade it.
\end{abstract}

Key words: Impact, Indian Politics, Information technology (IT), Technology.

\section{INTRODUCTION}

Technology is the advancement in stream of science. It "can be defined as anything involving the application of science and engineering." Technology is a vast subject. Literally, information technology is a technology which involves computers and many other devices for getting and passing information. Indian information technology industry consists of the two major components i.e. IT services and business process outsourcing (BPO). The United States accounts for $2 / 3^{\text {rd }}$ of India's IT services exports. ${ }^{2}$

As India is a diverse country, it is hard to manage it with one kind of technology. For this various types of technological interventions are applied in Indian politics specifically in the today's age of digitalisation. As we know elections are the basic of politics. It is like a food to the body of politics. If we combine the term technology with elections then, elections and technology can be referred to "software programs and electronic equipment, such as computers, printers, scanners, bar code readers and the Internet. But there are other technologies used in elections that do not directly involve computers, but rather new materials, such as cardboard, fibreglass and plastic used in polling equipment." 3

In India, information technology is used on large scale in the political arena. But political communication has always been burdened with many obstacles. It is inherently intricate due to elections and large scale communication. For this, communication technologies are used at every level. Generally, communication technology is a broad concept which is used as a medium to communicate with voters with the help of television, radio, telephone, internet, etc.

Over the years, the Indian politics has gone through tremendous transformation. Amidst these, some changes are positives while others end as bittern experiences. The most positive changes in the Indian political system with the advent of information technology are transparency and accountability. With the help of IT, now public has become more aware about their role as the citizens. People know about dos and don'ts in political system. The technology has changed the life of many and makes it simple and more responsive. Although,these positives vibrations are only one side of the coins as stated earlier. The dark side is really pathetic. No one can deny that the information technology has bring positivity to Indian politics but on the other side, it has bring some negativity also as now social media has become a platform to influence prospective voters. Things are exaggerated unnecessary with the use of information technology where as many times grounded realities are different. If we gaze upon literature available on the same then, shortage of relevant literature is the first hindrance that author went through. Although, enough literature is available on information technology and also on Indian politics but when we tried to study the impact of information technology on Indian politics then, sufficient literature is not available. Although, some articles and papers are there but there is shortage of research papers on the same. Here, the author has tried to fill this gap by systematically study this topic and providing the fruitful insight into the impact of information technology on Indian politics.

\section{OBJECTIVES}

The main objective of this paper is to analyse the impact of information technology on Indian politics 


\section{RESEARCH METHODOLOGY}

The research methodology is explanatory in nature and for data collection; it is confined upto only secondary sources which includes journals, websites, etc.

Limitations: There is a large scope for doing active research on the information technology and Indian politics as here, the author has focused only on impact.

\section{ANALYSIS}

To analyse the impact of information technology on Indian politics, the author has presented the description with the help of different headings and sub-headings. It contains both positive and negative impacts. The detailed analysis is as follows:

\section{Positive impacts}

A. Technologically mediated communication channels: In Indian Politics, information technology is used widely on every level of communication. "According to Author Bruce Gronbeck, the various functions of campaigns - winning the battle of ideas, converting and mobilising supporters, providing supporters informational claims and topics, and so forth-are normally carried out through technologically mediated communication channels." 4 This shows that technology has simplified the political communication. It has eased the channels and made tangible things simple.

B. Helps in decision making: Politically, every decision should be correct if any political party want to survive in the long run. One wrong decision can ruin their image. As for Congress, the Bofors deal done decades ago has become irksome for them even today. Now, "political parties use communication technologies to not just solicit votes, but also help their core committees make important decisions based on public mood. Therefore, it would not be far-fetched to conclude that politics itself is changing thanks to advancements in communication technologies." 5 This shows that communication technology is helping the politicians in taking right decisions at right place on right time.

C. Technological intervention in Indian Elections: Indian elections has underwent a major changes with the usage of technology as "a major push to use of technology in the Indian elections came with the use of electronic voting machines (EVMs). It entirely disrupted the way the elections were conducted. ...It was a paradigm shift for everyone including the political parties, candidates and the voters." This indicated that EVM has replaced the earlier ballot system and also helped in ensuring transparency in Indian elections. Now, every election whether General elections or Legislative Assembly elections all are conducted with the help of EVM machines.

D. Use of technical device: To ensure, fair elections, "An additional technical device called VVPAT (Voter-verified Paper Audit Trail) machine has been introduced to instil the confidence among the stakeholders. The voter can view the symbol of the candidate of his choice on the screen of VVPAT machine after casting his vote by pressing the button of the EVM." ${ }^{6}$ This underlined the fact that Indian politics is committed to SMART elections. Here, the abbreviation SMART means Simple, Moral, Accountable, Responsive and Transparent.

E. Change the methods of targeting voters: The advancement of technological interventions has altered the methods for targeting voters. The image given below show the difference between traditional method and new methods of targeting voters:

\section{Targeting Voters Traditional || New Methods Methods $\quad$ Profiling voters according to age and caste \\ Booth-wise caste and religious profiling \\ Targeting community or religious leaders to woo their followers \\ Engaging one dedicated agent (call volunteer) for 50-100 voters \\ Focusing on local NCOS, women self-help groups etc

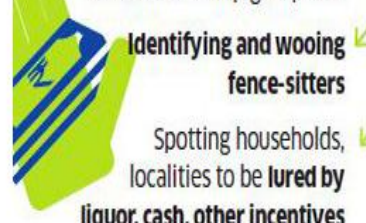 groups and targeting them with customised voice messages of political leaders \\ $\checkmark$ Use of apps, social media and missed calls to collect voters' personal data \\ $\checkmark$ Use of Facebook, WhatsApp etc to target young and first-time voters \\ $\searrow_{\text {spotting influencers with smartphones, like }}$ the headmaster of the only school in a village \\ $\checkmark$ Use of eps in campaign vans to increase efficiency \\ Micro-managing of a polling booth, with collection of real-time voting data (for instance, if only $20 \%$ voting takes places in a booth by 12 noon, there will be extra effort to get supporters to vote)}

Figure 1: Methods of targeting voters

Source:

https://ourdataourselves.tacticaltech.org/posts/overviewindia/

This indicated that things have changed in terms of methods also.

F. Use of technology in connecting to people: In the $21^{\text {st }}$ century, political leaders of India are techno-friendly. They understand the significance of information technology in their victory. That is why; they always try to discover new tactics to attract voters. The same is done by BJP in General Elections. With the help of technology, they created NaMo number to get in touch with more and more peoples. To spread information about the same, they took the help of information technology. The image mentioned below provide an information about NaMo number: 


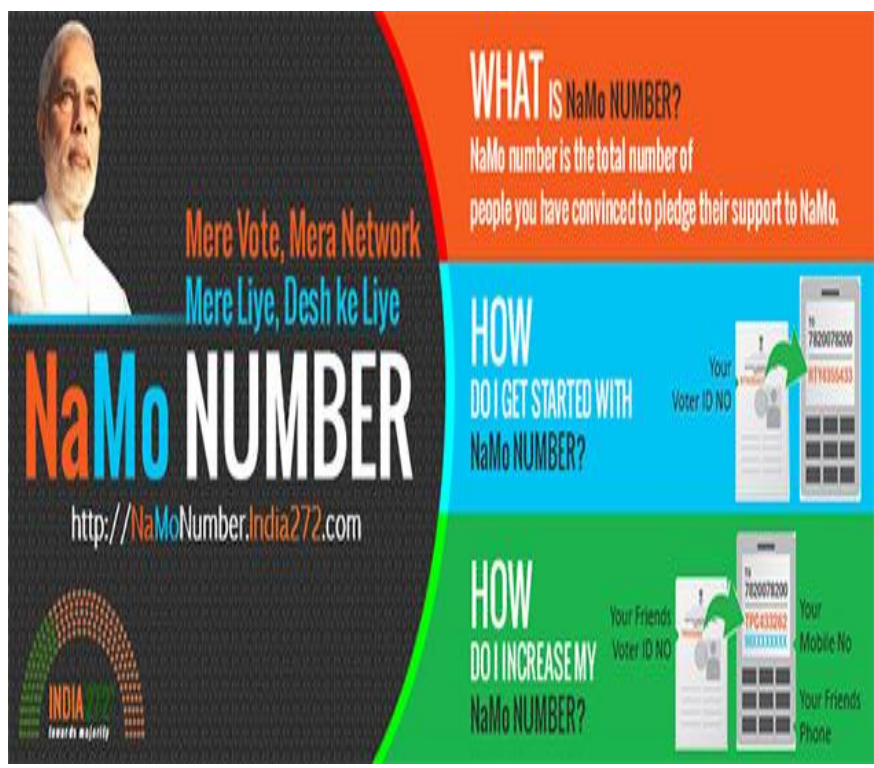

Figure 2: Details of NaMo Number

Source:

https://ourdataourselves.tacticaltech.org/posts/overviewindia/

It can be said that indeed this number has helped a lot the party in gaining popularity among the common masses.

G. Fundraising: Finance is the backbone of nation economy and we cannot deny the prominent role of funds in Indian politics. Here the technology helps in fundraising in both online and offline mode. "In the case of offline fundraising, list enrichment and segmentation can be very helpful in targeting audiences for different asks. And email marketing and marketing automation skills, and paid digital media (Facebook, Twitter, LinkedIn, etc.) can be helpful in driving "e-commerce"-style fundraising."

${ }^{7}$ This shows that technology has helped in getting financial support.

\section{Negative Impacts}

A. IT sector more driven by politics than technology today: Things used to occur in two-way process. If we are creating impact on anything in present time then, that thing will surely leave its impact in nearby future. The same incidence is happening with IT sector. Initially, it was IT which impacted the Indian politics but now due to political uncertainties of other parts of the world, Indian IT sector is getting affected. As "The Indian Information Technology (IT) sector is witnessing its worst slowdown since the global financial crisis of 2008. The sector is facing headwinds due to political uncertainties in the United States (US) and parts of Europe." ii This indicated that politics has deeply affected the technology.

B. Digital Fraud: At the basic level, a well-designed website helps in getting more volunteers and acts as a place. But on the other hand, it has also increased the chances of digital fraud by providing wrong or incomplete information about the political parties and their leaders.

C. Invitation to trouble: in India, illiteracy is still there. Sometimes, information technology creates a negative impact on the citizens as they are unable to get check the authenticity of information and invite trouble for themselves.

D. Require Skill: "The skills needed here are graphic design, basic web design (which has declined thanks to tools like Squarespace, Wix, etc.), and copywriting, and then applying that to social locations as well (Facebook, Twitter, Instagram, and Snapchat profiles).,"8 It is difficult to find suitable person.

E. Emergence of fakeness: due to paid digital media, the information technology also hampers the path of clean politics. As, these days "paid digital media on places like Facebook, visitors on campaign websites, social audience engagement, and even email marketing all is full instrumented, this provides for a feedback loop that warrants analysis and appropriate action - whether further investment, or to cut bait on a message that doesn't work, which allows focus elsewhere." "iii This shows that politics is losing its purity.

\section{CONCLUSION}

After going through the detailed analysis on the impact of information technology on Indian politics, it can be said that there both positive and negative impacts. As, the massive technological intervention in Indian politics has certainly made it more transparent. It helped in conducting fair elections for a true democracy. The need of the hour is to minimise the negative impacts and maximise the positive impacts. As in the age of digitalisation, we cannot ignore technology. We should try to use the information technology to make the Indian politics more responsive not to degrade it India politics is complex to understand as on the upper level, it seems that we have adopted democracy and things are working as per the provisions of Indian constitution. But due to corruption, the politics has lost its charm. Politicians should try to bring this charm back with the proper, efficient and effective use of information technology in Indian politics.

\section{REFERENCES}

1. Elections and Technology, Available from https://aceproject.org/ace-en/topics/et/onePage

2. Information technology in India, Available https://en.wikipedia.org/wiki/Information_technology_in_India

3. Elections and Technology, Available from https://aceproject.org/ace-en/topics/et/onePage

4. Kaveri Reddy (15 April, 2019, "How Communication Technology Is Transforming Indian Politics,"Available https://inc42.com/resources/how-communication-technology-is-transf orming-indian-politics/

5. Ibid. 
6. Jitendra Sinha(4 January, 2019), “ Technological intervention in Indian Elections," Available https://timesofindia.indiatimes.com/readersblog/humblyspeaking/tech nological-intervention-in-indian-elections-1028/

7. Ibid.

8. Quora (26 October, 2017), "What Role Will Technology Play In Politics?" Available https://www.forbes.com/sites/quora/2017/10/26/what-role-will-techn ology-play-in-politics-session-tech-for-campaigns/\#6a6f942d3cac

9. Prateek Shukla(30 June, 2017), “IT Sector More Driven By Politics Than Technology Today"Available http://www.businessworld.in/article/-IT-Sector-More-Driven-By-Polit ics-Than-Technology-Today-/30-06-2017-121179/

10. Quora (26 October, 2017), "What Role Will Technology Play In Politics?"” Available https://www.forbes.com/sites/quora/2017/10/26/what-role-will-techn ology-play-in-politics-session-tech-for-campaigns/\#6a6f942d3cac

11. Ibid.

\section{Author Profile}

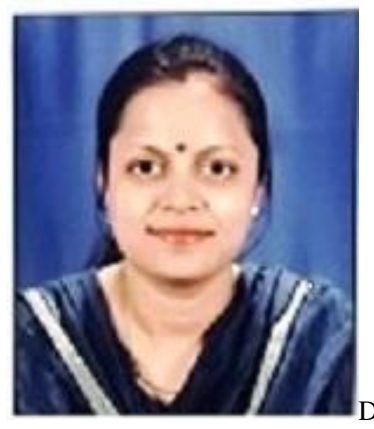
the Dadri (Haryana), India. She is a motivated professional and an ambitious academician. She has an excellent academic record and received University Research Scholarship (URS) from M. D. University for a Ph.D. degree for the years 2012-15.

She is Editorial Board Member as a reviewer for many International and National Journals of repute like Politikon, publication of the International Association for Political Science Students (IAPSS), Netherlands (ISSN 1583-3984) and Asian Social Science, Canada (ISSN (online): 1911-2025). She is a member of International Political Science Association (Canada) and Indian Political Science Association. Her areas of expertise are Indian Constitution, Public Personnel Administration and Gender Studies.

She is continuously working in the research field and has written extensively on various subjects which have not only presented in various National and International seminar/ conferences in India and abroad but have also been published as research papers and chapters in the journals of National and International repute. 